\title{
Preferential Trade Agreements
}

\author{
Prof. Asoc. Dr. Darjel Sina
}

Dean of the Faculty of Law at Luarasi University; Email: darielsina2002@yahoo.com

\section{MSc Krisi Kllapi}

Master student at the University of Bern International Law and Economics; Email: krisi-kllapi@live.com

\section{Doi:10.5901/ajis.2015.v4n3s1p436}

\section{Abstract}

The WTO stifles the possibility of developing countries to utilize trade as a means to economic growth and development. Requirements to implement WTO rules are at odds with development ideals- and countries simply try to implement these rules in such way that can give them more opportunities, profits and contribution to the attainment of development goals. One important trend in recent years in the field of trade policy is the proliferation of preferential trade agreements (PTAs). Normally, PTAs provide for greater levels of liberalization among the parties than what the countries may have committed to at the WTO in terms of tariffs or services liberalization. The new generation of PTAs tend to contain disciplines which go beyond relevant WTO disciplines, or regulate issues in respect of which there are no WTO disciplines. One example is the agreement that the European Union has signed with South-East European countries. This agreement deviate from the purely trade-focused purpose but it includes other broader intentions. But still many developing countries are addressing the fact that they are not benefiting from the WTO system and they are claiming that the cost of adjustment to its rules is higher than the advantage of being part of the WTO. One of the main problems addressed by developing countries is the reciprocity of the market access concession. The WTO should face this problem and try to find suitable solutions with minor costs for the members.

Keywords: reciprocity, market access, concession, rules, tariffs.

During the first days of the GATT times the decision making process was in the hands of the developed countries. The GATT institution was considered as a "rich man club" where developing countries did not fully participate in the exchange of concession during the process negotiation ${ }^{1}$ although they benefited from the system as a result of the national treatment and the Most Favored Nations disciplines. In the WTO era things changed in many aspects. The WTO is much more a "developed concerned" institution creating a new agenda and new mechanisms in order to give assistance to developing countries and creating a new instruments and new systems where decisions are made by consensus and not by taking into consideration only the developed country needs. Special steps in this regard were undertaken during the different rounds of the GATT/WTO which consisted in longer tariff-phase down period, flexibility in implementing the GATT/WTO rules and disciplines, preferential market access, technical assistance etc. ${ }^{2}$. In comparison to the past, nowadays developing countries are more and more involved in signing trade agreements trying to get as much benefits as possible out of the system. The number of these agreements has created a complex and overlapping network with voluminous agreements by hardening their applications creating the "spaghetti bowl" effect. We must say this is a relatively new trend in world trade, because couples of decades ago the rules of trade were very different. The inter-war period was a dark period for the world trade system. When World War II started the tariffs were high everywhere and trade had collapsed to 70 per cent of its level on 1928 level. The US's 1930 Smoot-Hawley tariff had sparked tariff wars and defensive trade blocs ${ }^{3}$. After twenty years, in the $50 \mathrm{~s}$, the rules of world trade started to change. This was mainly a

${ }^{1}$ Hoekman, B M\&Kostecki, M.M. The political economy of the world trading system, Oxford university press 2009, pg. 532.

${ }^{2}$ Fazel, I. Mainstreaming development in the World Trade Organization, journal of trade law 39 (1) 2005, pg.15.

${ }^{3}$ The World Economy, 2006, (accessed 5 December 2014), doi: 10.1111/j.1467-9701.2006.00852.x@ 2006 The AuthorJournal compilation (c) 2006 Blackwell Publishing Ltd, 9600 GarsingtonRoad,Oxford, OX4 2DQ, UK and 350 Main St, Malden, MA, 02148, USA 1451Blackwell Publishing Ltd Oxford, UK TWEC Wo 0378-5920 @ 2006 Blackwell Publishers Ltd (a Blackwell Publishing Company) November 2006 29110riginal Article MULTILATERALISING REGIONALISM RICHARD E. BALDWIN rld Economy Multilateralising 
result of the economic institutions created during Bretton Woods ${ }^{4}$ and in particular of General Agreement on Tariffs and Trade. This agreement had an importance on the reduction of the customs tariff and on the liberalization of the trade. Since then trade agreements and in particular Preferential Trade Agreements (PTAs) have been proliferating. This proliferation has happened especially for the last twenty years. A large literature has studied various aspects of this phenomenon. Recently a major weakness of this literature has been the treatment of all PTAs as equal 5 . In fact, PTAs are not standard and differ significantly in terms of design, institutions, scope, actors involved etc. Some agreements, such as the European Union (EU) or the North American Free Trade Agreement (NAFTA), are very broad and are not limited only on trade issues. They also include trade in services, foreign investment, property rights, intellectual property rights, government procurement, product standards, completion law, rules of origin, environmental issues etc. ${ }^{6}$. They are more forward-looking, wide-ranging bilateral trade and investment agreement which will be not isolated only to one specific geographic region or signed only by a reduced number of states. For instance, the EU has PTA with countries are geographically close such as Western Balkan countries but on the other hand it has also PTA with far-away developing countries such as Chile, Mexico, South Africa etc. and poor developing countries in Africa, Caribbean and Pacific (the ACP countries). The porpoise of singing such agreements is driven by different reasons which go far beyond the WTO framework and rules.

The FTA between EU the Western Balkan countries, Albania, Bosnia-Herzegovina, Macedonia, Montenegro and Serbia its part of the broader Stabilization and Association Process which aim to harmonize, align and exchange the institutional and legal reforms of these countries as E.U candidate members ${ }^{7}$. These agreements aim to overcome the consequences of the communist regime of these countries as well. It's clear that the aim of this agreements goes far beyond trade and its more geo-political focused. On the other hand, EU has agreements which are comprehensive on the geographic aspect. More and more these agreements are ambitious including states with great distance and simultaneously by focusing on to the trade tariffs. The EU is more active since 2006 by undertaking some Free Trade Agreements of new generation, which have as scope the achievement of the high standards of liberalization, especially on the emergent trades which have high rate of development such as India and Korea which include liberalization of tariffs, non-tariff barriers, and services, plus new disciplines in the areas of competition policy, intellectual property rights, labor, and the environment ${ }^{8}$. Many of these agreements refer to commitments in policy areas not currently covered or regulated by the WTO. For instance, there are no current WTO undertakings with regard to environmental protection, labor laws, human rights, or movements of capital9.

According to some studies, E.U and U.S. PTAs tend to cover WTO-plus and WTO-extra provision, in the coverage of services (in the financial and telecommunication services) and IPR. The US uses the "negative" list approach compared to the GATS approach of a combination of positive and negative lists. The EU treatment of services and IPR, according to the London School of Economics study, is less ambitious than the U.S. approach, because it uses a positive-list approach that provides the flexibility to exclude sensitive sectors both for itself and its trading partners. However, this agreements are not WTO inconsistence, but they are a clear example of the fact they nowadays PTA are broader and tend to include many other sectors then the sectors mentioned by the WTO in order to achieve higher regulative standards and more effective results. But still, there are plenty of agreements which are narrow and exhibit modest commitments. ${ }^{10}$

We can say that nowadays PTAs are more and more ambitious in the terms of the sectors included. Members are not limiting their agreements only to the WTO rules but they go far beyond. Not only the sectors included are more

Regionalism:Spaghetti Bowls as Building Blocson the Path to Global Free TradeRichard E. BaldwinGraduate Institute of International Studies, Geneva.

${ }^{4}$ World Trade Organization, The GATT years: from Havana to Marrakesh, (accessed 5 December 2014), http://www.wto.org/english/ thewto_e/whatis_e/tif_e/fact4_e.htm.

${ }^{5}$ The Design of International Trade Agreements: Introducing a New Database Andreas Dur, Manfred Elsig, KarolinaMilewicz Leonardo Baccini Paper prepared for the 25th conference of the German Political Science Association, Tubingen, September 24-28, pg. 2.

6World Trade Organization, World Trade Report 2011, (accessed February 2015), http://www.wto.org/english/res_e/booksp_e/anrep_el world_trade_report11_e.pdf,pg. 50

${ }^{7}$ Ahearn, J. R. Europe's Preferential Trade Agreements: Status, Content, and Implications, March 3, 2011, pg. 5

${ }^{8}$ Ahearn, J. R. Europe's Preferential Trade Agreements: Status, Content, and Implications, March 3, 2011, pg. 14

${ }^{9}$ Ahearn, J. R. Europe's Preferential Trade Agreements: Status, Content, and Implications, March 3, 2011, pg. 17

10The Design of International Trade Agreements: Introducing a New Database Andreas Dur, Manfred Elsig, Karolina Milewicz Leonardo Baccini Paper prepared for the 25th conference of the German Political Science Association, T"ubingen, September 24-28 pg. 2 
numerous but also the practices of negotiations have changed. They are more transparent and are trying to eliminate every information asymmetry and are including more non state actors such as Multinational Corporations and NGO. Another important thing to bear in mind is that today members are involved in the negotiations of mega agreements such as the Transatlantic Trade and Investment Partnership. In such kind of ambitions agreements is difficult for the members involved to stay strict within the WTO provision because they include many interests and many state, non-state actors. So, this new generation agreements shall include and regulate issues in respect of which there are no WTO disciplines. This will increase the effectiveness of the agreement and the benefits of the actors involved.

But still many developing countries are addressing the fact that they are not benefiting from the WTO system and they are claiming that the cost of adjustment to its rules is higher than the advantage of being part of the WTO. To some extend I agree with this statements for different reasons. First of all, one of the main problems, which were addressed by developing countries, is the reciprocity of the market access concession. This problem was raised especially from the small developing countries, some of them located in remote part of the world, which are of only limited interested from an export perspective ${ }^{11}$. That's why the reciprocity principle does not work for them. Another problem is the tariff reduction cause for developing countries tariff revenues are fundamental and they economically rely on them. Some of the developing countries claim that don't have the capacity to tap the tariffs. Another important point is the protection of infant industries which is very important form a development perspective. Very important issue is also technical assistance provided by the WTO toward developing and Least Developing Countries (LDC). The question that is rising in this regard is how the country is actually benefiting from the WTO aid and is the aid helping the key developing sectors of the specific county? As a result we can argue that some of the common policy under WTO are not feasible for developing countries or at least, for some of them. Other policies like technical assistance are limited and are not really strategic. That is the reason why some of the developing countries are skeptical about the WTO system and are blaming the developing countries for kicking the ladder being them because they are not allowing developing countries to use practices and instrument utilized by them in their developing process ${ }^{12}$. But what can the WTO actually do for the developing countries and LDC in order to make them benefit from the international trade rules and to foster their development? In the WTO legal text developing countries and LDC have special and differential treatment which basically include: Provisions aimed at increasing the trade opportunities of developing country Members; provisions under which WTO Members should safeguard the interests of developing country Members; flexibility of commitments, of action, and use of policy instruments; transitional time-periods; technical assistance; Provisions relating to LDC Members.

I think that the WTO has to move from just setting timeframes and general provisions. It has to apply a more case by case approach because the developing needs of different countries are not the same. Like the Trade Facilitation Agreement, an outcome of the Bali Ministerial meeting, the WTO has to incorporate rules and mechanisms for trade expert in order to identify why a developing country is not able to implement commitments within the scheduled timetable. After identifying the specific problem of the country the group of experts, should try to analyze the situation and to find solution to the problem ${ }^{13}$. An important point to add is that the WTO structures should work together with the government and local entities. On the other hand the government should implement a legal system which complies with the WTO developing program. They should also give space to countries and their developing concerns regarding cost and capacity constrain. On the focus should be also the technical assistance. One of the challenges is to provide more funds in order to make more investments in infrastructure, ports, roads, training people etc. It is also very important to find out specific strategic developing sectors, of the specific country or region and to put in place mechanisms to make them more effective and efficient. In my opinion another issue to take into consideration is the fact that there is huge gap between the developing countries group. This means that some developing countries such as India, South Africa or Brazil are treated in the same way as countries as Cabo Verde, Burkina Faso or Macedonia. I think that special classification should be made in this regard in order to address properly the special needs of some of the developing countries

\section{Conclusions}

As conclusion I would like to add that there are number of ways to look at the WTO. This international organization is a

\footnotetext{
${ }^{11}$ Hoekman, B M\&Kostecki, M.M. The political economy of the world trading system, Oxford university press 2009, pg. 533.

12Fazel, I. Mainstreaming development in the World Trade Organization, journal of trade law 39 (1) 2005,pg.15.

${ }^{13}$ Special and Differential Treatment Provisions In WTO Agreements And Decisions, Word Trade Organization, 14 June 2013, (accessed on 14 March 2015), http://www.voxeu.org,pg. 4.
} 
negotiation institution, a dispute settlement body etc. One of the purposes of the WTO is to boost international trade and to increase the benefits of the members from the rules in place. Some scholar thinks that it is a developing institution some other thinks the opposite. What is surly try is that the WTO is doing a lot in negotiating with members on trade, and sometimes on non-trade issues. This is not an easy process. Adequate national regulation and international regulatory cooperation will often need to take place for the process to move on ${ }^{14}$. Things become even more difficult when parts of the whole process are many parties with different needs. That is why the WTO should move forward in order to implement more politics and sing new agreements in order to facilitate the process and to make every one better-off.

\section{References}

Ahearn, J. R. Europe's Preferential Trade Agreements: Status, Content, and Implications, March 3, 2011.

Europes Preferential Trade Agreements Status, Content and Implications; Raymond Ahearn 2011; Congressional Research Service, file:///C:/Users/Hp/Downloads/01_WTO\%20(2011)\%20WTO\%20and\%20Preferential\%20Trade\%20Agreements\%20\%20Executive\%20Summary\%20pp.5-17\%20(2).pdf.

Private Actors and Public Governance Beyond the State: The Multinational Corporation, the Financial Stability Board and the Global Governance Order, Pennsylvania State University - Dickinson School of Law, 2010, (accessed 5 December 2014), http://papers.ssrn.com/sol3/papers.cfm?abstract id $=1658730$.

Thornton, P. B, Multilateralsing Regionalism: Ideas for a WTO action plan on regionalism, 2007, (accessed 5 December 2014), http://www.amazon.com/Multilateralising-Regionalism-Ideas-Action-Plan/dp/1898128995.

The World Economy, 2006, (accessed 5 December 2014), doi: 10.1111/j.1467-9701.2006.00852.x @ 2006 The Author Journal compilation @ 2006 Blackwell Publishing Ltd, 9600 GarsingtonRoad,Oxford, OX4 2DQ, UK and 350 Main St, Malden, MA, 02148, USA 1451 Blackwell Publishing Ltd Oxford, UK TWEC Wo 0378-5920 @ 2006 Blackwell Publishers Ltd (a Blackwell Publishing Company) November 2006 2911Original Article MULTILATERALISING REGIONALISM RICHARD E. BALDWIN rld Economy Multilateralising Regionalism: Spaghetti Bowls as Building Blocs on the Path to Global Free Trade Richard E. Baldwin Graduate Institute of International Studies, Geneva.

World Trade Organization, The GATT years: from Havana to Marrakesh, (accessed 5 December 2014), http://www.wto.org/english/ thewto_elwhatis_eltif_elfact4_e.htm.Regional Trade Agreements and Dev Countries ( pertu pare) p 6-7. 